\title{
Assessment of the Contribution of Urban Crop Production to the Socio- Economic Development of Benue State, Nigeria
}

\author{
Atagher, Monica Mwuese $^{1 \mathrm{a}}$, VER, Abraham ${ }^{1 \mathrm{~b}}$, Akor Apollos ${ }^{2}$ \\ 1a. Department of Agricultural Business Management, Akperan Orshi College of Agriculture Yandev, P.M.B \\ 181, Gboko Benue State, Nigeria. \\ ${ }^{1 b .}$ Department of Agricultural Business Management, Akperan Orshi College of Agriculture Yandev, P.M.B \\ 181, Gboko Benue State, Nigeria. \\ 2. Department of Cooperative Economics and Management, Akperan Orshi College of Agriculture Yandev, \\ P.M.B 181, Gboko Benue State, Nigeria.
}

\begin{abstract}
This study was undertaken to assess the contribution of urban crop production to the socioeconomic development of Benue State, Nigeria. Multi-stage sampling technique was adopted to select 210 urban crop farmers across three major towns (Gboko, Makurdi and Otukpo) in Benue State. Data analysis was through descriptive statistics and Cobb-Douglas production model. Results showed that most respondents were educated, married and had primary occupations, but used urban agriculture to augment their food supplies and income. Regression results showed that the coefficient of determination $\left(R^{2}\right)$ was 0.519 suggesting that $51.9 \%$ of the variation in output was predicted by variables included in the model. The F-Ratio (55.29) was significant at $5 \%$ level of probability indicating that the model was well specified. Furthermore, $t$-tests showed that farm size $\left(X_{1}\right)$, amount of fertilizer applied $\left(X_{3}\right)$, and the quantity of seeds and other planting materials used $\left(X_{4}\right)$ were significant determinants of respondents' output and productivity. Therefore, to improve productivity across urban farms in the study area, the study recommends enhancement of urban farmers' access to bigger farm sizes, fertilizers, improved seeds and planting materials, and extension education on suitable food production and consumption choices.
\end{abstract}

Key words: urban agriculture, urban crop production, socio-economic development

\section{Introduction}

Cities in sub-Saharan Africa (SSA) are growing very fast. The United Nations (UN, 2008) observed that with an annual rate of $3.7 \%$, the current urban growth rate in SSA is almost double the worldwide average, and by 2030, half of Africa's population will be urban. At the global level, Garrett (2000) projected that by 2020 the number of people living in developing countries will grow from 4.9 to 6.8 billion, $90 \%$ of this expansion will be in cities and towns accounting for more than half the population of Africa and Asia. According to UNICEF (1995) poverty and malnutrition are becoming increasingly urban. More of the rural poor are migrating to the cities, more of the people in cities are being born in poor families and more urban middle class residents gravitate around the poverty line. If in 1988 at least 25 per cent of the developing world's absolute poor were living in urban areas, by year 2020 these are expected to comprise 65 per cent of the world's poor households.

As one of Africa's most urbanised countries, Nigeria's population is projected to hit 168.2 million with an urban population of 97.9 million by 2020 (Adeyemo and Kuhlmann, 2009; Salau and Attah, 2012). The Nigerian situation is particularly pathetic as the accepted socio-economic profile shows that about 70 per cent of Nigerians live below the poverty line (Ogungbile, 2008). The high rate of urbanization, weakened purchasing power, high incidence of poverty, retrenchments in public and private sectors and high unemployment rate have curtailed the capacity of both the urban poor and middle class to purchase all the food they need. This is given the fact that most households in Nigeria spend an average of 50-80 percent of their income on food (NBS, 2006; Egbuna, n.d). Consequently, Olaniyi (2011) warned that if no action is taken, the rapid rate of urbanisation combined with lack of economic growth in the rural areas, will exacerbate unemployment, poverty and urban food insecurity problems over the next two decades. Idowu (2012) observed that agriculture used to be primarily a rural activity in Nigeria, but due to the increasing high demand for food and jobs for many urban dwellers, it became necessary for urban households to embark on urban agriculture as a means of filling the food demand and supply gap, and to earn income for other requirements. According to Egbuna (n.d.) the ability to earn cash income is a significant determinant of poverty reduction and perhaps the biggest challenge urban dwellers face is that the majority of them work in sectors where wages are low, working conditions precarious and job tenure insecure. Consequently, most urban dwellers turn to urban agriculture for survival.

Urban agriculture (UA) is defined as the production of food such as vegetables fruit, meat, eggs, milk, fish and non-food items such as fuel, herbs, ornamental plants, tree seedlings, flowers and others within the urban area and its periphery for home consumption and/or urban market, and related small scale processing and 
marketing activities. Urban agriculture takes place on private, leased or rented land in peri urban and urban backyards, rooftops, on vacant public lands such as industrial parks, school grounds, roadsides, in prison and other institutions, in ponds, lakes and rivers (Reuther and Dewar, 2005; Kekana, 2006; FAO, 2007; Hovorta, Zeeuw and Njenga, 2009; Salau and Attah 2012). Mougeat (2005) described UA as industry located within (intra-urban) or on the fringes (peri-urban) of a town, city or a metropolis, which grows and raises a diversity of food and non-food products, (re) using largely human and material resources, products and services largely to that urban areas. For this study, urban agriculture is defined as the production of crops and livestock within, and around Gboko, Makurdi and Otukpo towns of Benue State, Nigeria.

Available evidence indicates that urban agriculture is a worldwide activity. Smith et al (1996) estimated that 800 million people are engaged in UA worldwide; of these, 200 million are market producers, employing 150 million people full time. Studies also suggest that $40 \%$ and $50 \%$ of the urban dwellers in Africa and Latin America respectively are involved in some sort of agricultural activity (UNDP, 1996; Reul et al, 1998; Zezza and Tasciotti, 2010). Hence urban agriculture has become a contemporary issue, gaining prominence especially in developing economies because it has been discovered to be a viable poverty intervention strategy for the urban poor, since it contributes significantly to the socioeconomic development of cities throughout the world (Akpabio et al, 2007; Olaniyi, 2011; Salau and Attah, 2012). According to Umoh (2006) the factors responsible for the steady increase in UA (especially in Nigeria) include the rise in food prices, un-employment and inflation brought about by structural adjustment, and the decline in the real incomes of both rural and urban households. Idowu et al (2012) have maintained that the rapid movement of people from the rural areas into the towns and cities (urbanization) is the main driver of urban agriculture, because in many countries rapid urbanization is usually followed by increasing urban poverty, food insecurity and malnutrition, and has given birth to a large class of urban poor in many developing countries including Nigeria.

According to Cofie (2008), some of the challenges associated with the practice of urban agriculture include: urban farmers are poorly organised, are more dispersed and have a strong variation in social background; increasing demand for land by estate developers for housing and commercial facilities which thus reduces access to lands for farming activities; farming within the cities is also associated with health hazards through the use of untreated wastewater for crop irrigation; financial assistance (from banks and other institutions) is difficult to obtain due to insufficient collateral and the long term nature of agriculture.

However, the benefits of urban agriculture are many (Okolo, 2006; Olaniyi, 2011; Salau and Attah, 2012). These include provision of adequate food, employment, supplementing income, and production of important nutrition not normally available to low-income households. Moreover, households involved in UA may have direct access to comparatively cheaper food, and a wide variety of nutritious foods such as vegetables and animal products like eggs, milk and meat. This is more nutritious compared to a situation where the supply of these comes from long distances, and take time arriving, with subsequent loss of valuable micronutrients (Landon- Lane, 2004; Reuther and Dewar, 2005; Kekana, 2006). Studies further indicate that farming in urban environments benefits poor households through direct savings on food purchases, income generation through the sale of produce, and provision of a varied range of nutritious products. Nevertheless, the greatest proportion of urban agriculture is undertaken as a survival strategy by individual households, generally in backyards to augment household real income (Idowu et al, 2012). In a stud of 15 countries in Africa (including Nigeria), Asia, Latin America and Eastern Europe, Zezza and Tasciotti (2010) established that there exist a positive association between urban agriculture and indicators of dietary adequacy. They found that households that engaged in urban agriculture were more likely to consume more calories, enjoy a more diverse diet, and have greater access to a greater number of calories from basic staples, fruits and vegetables.

In spite of the importance of urban agriculture, Nigerian policy makers and government have deliberately neglected this veritable sector and have failed to give it official recognition and attention, but merely tolerate it as a response of the poor towards adverse socio-economic conditions facing them (Egbuna, n.d.; Lynch et al, 2002). However, Zezza et al (2008) and Dessus et al (2008) noted that events from the recent world food price crisis have rendered the importance of understanding and confronting the causes of food insecurity of the urban poor even more apparent. This, they explained is because poor urban dwellers, being largely net food buyers and depending mostly on markets for their food supplies, are particularly vulnerable to adverse food price shocks, and are consistently the group in society that suffers most from higher food prices. Therefore, analyzing the extent to which urban agriculture might help shield the urban poor from some of these shocks becomes paramount. It is against this background that this study was undertaken to assess the contribution of urban crop production to the socio-economic development of Benue State. The study strongly believes that given the level of poverty in Nigeria, urban agriculture could be harnessed as a strategy for poverty reduction. The specific objectives are to describe the personal characteristics of urban crop producers in the state; to identify the specific crop production enterprises embarked upon by urban crop farmers in the State; to determine why people farm within urban areas in the State; and to identify the determinants of productivity of urban crop producers in Benue State, Nigeria. 


\section{Methodology}

Study area, sampling and analytical technique. The study was carried out in Benue State. The State is named after River Benue, the second largest river in Nigeria and lies between longitude $8^{\circ} \mathrm{E}$ and $10^{\circ} \mathrm{E}$, and latitude $6^{0} 3^{\circ} \mathrm{N}$ and $812^{1} \mathrm{~N}$. The State has 23 Local Government Areas and shares boundaries with Nassarawa State to North, Kogi State to the West, Taraba State to East, Enugu and Cross River State to the South west, and Ebonyi State to the South. Benue State also shares an international boundary with the Republic of Cameroon. Agriculture is the dominant occupation of inhabitants of Benue State. Some of major agricultural products in the State include yams, cassava, sweet potatoes cocoyam, maize, rice, sorghum, soya beans, beniseed, groundnut, beans, oil palm, livestock, forestry products and fish (BNARDA, 2001).

Multi stage sampling technique was used for the study. The sampling frame for the study was all the urban crop farmers in Benue State, Nigeria. Stage one was the purposive selection of three major towns in Benue State namely Gboko, Makurdi and Otukpo. Stage two involved purposive selection of certain communities within these towns. These communities were official residential areas, indigenous population areas, migrant population areas, centrally and peripheral areas. Stage three was random selection of one ward from each of the above communities giving a total of five (5) wards per town. Finally, random selection of fourteen (14) urban crop producers from each ward giving seventy (70) respondents per town, and a total of two hundred and ten (210) respondents as sample size. Data was collected through structured questionnaire and personal observation. Descriptive statistics and the ordinary least square multiple regression techniques were used to analyse data. Cobb-Douglas production function was specified to identify the factors that affect the productivity of respondents in the study area. It was used because it is one of the most widely used functions in the economic analysis of the problems relating to empirical estimations in agriculture and industry, and it is easy to handle mathematically (Koutsoyiannis, 1979; Olayemi and Olayide, 1981; Sankhayan, 1988). The implicit form of the function is given as:

$$
\mathrm{Y}=\mathrm{b}_{0} \mathrm{X}_{\mathrm{i}}^{\mathrm{bi}} \mathrm{e}
$$

Where $\mathrm{Y}=$ valued output $(\mathbb{N})$

$\mathrm{b}_{0}=$ intercept

$\mathrm{X}_{\mathrm{i}}=$ variable inputs used

$b_{i}=$ regression coefficients of the variable inputs.

$\mathrm{e}=$ error term

The explicit form of the model is:

$$
\mathrm{Y}=\mathrm{b}_{0} \mathrm{X}_{1}{ }^{\mathrm{b} 1} \mathrm{X}_{2}{ }^{\mathrm{b} 2} \mathrm{X}_{3}{ }^{\mathrm{b3}} \mathrm{X}_{4}{ }^{\mathrm{b} 4} \mathrm{e}
$$

This was linearised according to (Koutsoyiannis, 1977) as follows:

$\log Y=b_{0}+\log X_{1}{ }^{b 1}+\log X_{2}{ }^{b 2}+\log X_{3}{ }^{b 3}+\log X_{4}{ }^{b 4}+e$

Where $\mathrm{Y}=$ estimated value of composite output (

$\mathrm{X}_{1}=$ cultivated farmland ( ha)

$\mathrm{X}_{2}=$ amount of labour used (man-days)

$\mathrm{X}_{3}=$ quantity of fertilizer used $(\mathrm{kg})$

$\mathrm{X}_{4}=$ quantity of seeds and planting materials used $(\mathrm{kg})$

$\mathrm{e}=$ error term

\subsection{Personal Characteristics of Respondents}

\section{Results And Discussion}

Table1 shows the distribution of respondents according to their personal characteristics. Respondents within the age bracket of 20-30 years were $10.48 \%$. Over half of the respondents $(53.81 \%)$ were within the age of $31-40$ years, $16.66 \%$ were within the age range of $41-50$ years while those above 50 years were $19.05 \%$. Altogether, $84.44 \%$ of the producers were below the age of 50 years. This implies that urban farmers in the study area energetic people who can effectively carry out urban farming activities because they are still in their active years. This finding is in line with Ogunlade et al (2007) and Olaniyi (2011) that people of this age category are considered to be young and able bodied who can still contribute immensely to a productive enterprise.

Results indicate that most of the respondents $(76.2 \%)$ were married, $20.5 \%$ were single while $3.3 \%$ were widowed, divorced or separated. Since most of the respondents were married, they could be practising urban agriculture to ensure food security and other needs of their families. Analysis showed that $74.3 \%$ of the respondents were males while $25.7 \%$ were females. This implies that urban agriculture in the state was dominated by males. This finding disagrees with Hovorka et al (2009), Salau and Attah, (2012) who reported that women were the majority of urban farmers worldwide. This could be as a result of the cultural norm in the study area where most farms are owned by the family and are regarded as belonging to the family head (who in most cases is a man). In such cases, the farms are regarded as family farms; the women work on the farms but are not considered as the real owners unless the household is female-headed. 
Table 1: Frequency Distribution of Respondents according to Personal Characteristics

\begin{tabular}{|c|c|c|}
\hline Personal characteristics & Frequency & Percentage \\
\hline \multicolumn{3}{|l|}{ Age (years) } \\
\hline $20-30$ & 22 & 10.48 \\
\hline $31-40$ & 113 & 53.81 \\
\hline $41-50$ & 40 & 19.05 \\
\hline Above 50 & 35 & 16.66 \\
\hline \multicolumn{3}{|l|}{ Marital Status } \\
\hline Married & 160 & 76.20 \\
\hline Widowed or separated & 7 & 3.30 \\
\hline Single & 43 & 20.50 \\
\hline \multicolumn{3}{|l|}{ Gender } \\
\hline Male & 156 & 74.30 \\
\hline Female & 54 & 25.70 \\
\hline \multicolumn{3}{|l|}{ Level of Education } \\
\hline No formal education & 15 & 7.14 \\
\hline Primary education & 39 & 18.57 \\
\hline Post primary education & 38 & 18.10 \\
\hline Higher education & 118 & 56.19 \\
\hline \multicolumn{3}{|l|}{ Primary Occupation } \\
\hline Civil servant & 120 & 57.14 \\
\hline Unemployed & 59 & 28.10 \\
\hline Self employed & 17 & 8.10 \\
\hline Full time farming & 14 & 6.66 \\
\hline \multicolumn{3}{|l|}{ Farming Experience } \\
\hline$\geq 10$ years & 106 & 50.47 \\
\hline $11-20$ years & 70 & 33.30 \\
\hline Above 20 years & 34 & 16.20 \\
\hline
\end{tabular}

Source: Field Data

Results further showed that $56.19 \%$ of the respondents had higher education, $18.57 \%$ had primary education, and $18.09 \%$ had post primary education while $7.14 \%$ had no formal education. Altogether, $92.6 \%$ of respondents had formal education. The high literacy level contrasts with the generally low literacy level in the country, and it is an indication that urban agricultural producers are not the normal farm workers, but educated people in urban areas using agriculture to augment income, food or both. This finding also means the respondents in the study are highly educated people who could successfully carry out innovative agriculture. This finding follows the assertion of Oladeebo and Ambe-Lamidi (2007) and Agbamu (2006) that educated farmers are prone to be highly innovative, and that formal education positively influences the adoption of improved agricultural technologies. It agrees with Onyeweaku et al (2004) that education increases productivity and enhances farmers' ability to understand and evaluate new production techniques. It also conforms to Nsikakabasi et al (2010), and Ajibefun and Aderinola (2004) that educated farmers tend to have higher yields and incomes from cultivated areas. This pool of highly educated farmers implies that there is high potential for improving UA in the study area.

Data analysis showed that $57.14 \%$ of the respondents were civil servants, $28.10 \%$ were unemployed, and $8.10 \%$ were full time farmers while $6.66 \%$ were self employed. This finding agrees with Foeken and Mirangi (2000), and Salau and Attah (2012) that most farming activities in urban areas were carried out on part time basis by people engaged in other occupations. Results further showed that $70.95 \%$ of respondents were into urban agriculture to argument their food supply, $42 \%$ were into urban farming to supplement their incomes while $2.86 \%$ said they did it as a hobby. This conforms to Idowu (2006) that most urban dwellers take to urban agriculture to meet their food security and income needs.

Data analysis further showed that about half (50 47.0\%) of the respondents had urban farming experience of $1-10$ years, a third (33.33\%) had been farming for $11-20$ years while $16.20 \%$ had been farming for over 20 years. This implies that most of the urban farmers must have acquired enough experience, relevant skills and other resources for effective farming. This is in line with Inoni (2008) that as the farmer gets older and more experienced, the more resources he commands to generate more income.

\subsection{Crop Enterprises by Respondents}

Multiple cropping was favoured by respondents in the study. Table 2 shows the various crops grown by respondents. Since most respondents grew more than one crop, the table has multiple responses. Table 2 shows respondents' preference for starchy staples such as yams, cassava, maize and guinea corn which are energygiving foods, and less of body building foods such as beans, fruits and vegetables. This implies that respondents emphasize the quantity aspect of food security more than the quality aspect. This is dangerous because it can lead to malnutrition. This result re-emphasizes Egbuna (n.d.) that poverty and malnutrition are becoming increasingly urban. 


\begin{tabular}{|lcc|}
\multicolumn{1}{c}{ Table 2: Frequency Distribution of Respondents' Crop Enterprises } \\
\hline Crop & Frequency & Percentage \\
Yams & 169 & 80.47 \\
Cassava & 120 & 57.14 \\
Maize & 92 & 43.61 \\
Guinea corn & 74 & 35.24 \\
Soyabeans/beans & 49 & 23.33 \\
Sweet potato & 28 & 13.33 \\
Rice & 25 & 11.90 \\
Tomatoes & 22 & 10.48 \\
Leafy vegetables & 14 & 6.67 \\
\hline
\end{tabular}

\section{Source: Field Data}

For a balanced diet and wellbeing, there is need to produce and consume not only energy giving foods, but also fruits, vegetables and pulses which build the body enabling it to remain healthy and active. The policy implication of this finding is that there is need to educate the populace about the need for production and consumption of foods that would maximise their overall wellbeing. This emphasises the need for education on the qualitative and quantitative aspects of food security.

\subsection{Reasons for Urban Crop Production by Respondents}

Table 3 showed that $70.95 \%$ of respondents were into urban farming to argument their food supply, $42 \%$ were into urban farming to supplement their incomes while $2.86 \%$ said they did it as a hobby.

TABLE 3: Frequency Distribution of Respondents' Reasons for Urban Crop Production

\begin{tabular}{|llc|}
\hline Reason For Production & Frequency & Percentage \\
To get enough food & 149 & 70.95 \\
To supplement salary/income & 90 & 42.86 \\
As a hobby & 5 & 2.40 \\
\hline
\end{tabular}

\section{Source: Field Data}

This in line with to Idowu (2006), Umoh (2006), Okolo (2006), the National Bureau of Statistics (NBS, 2006) and Olaniyi (2011) that access to adequate food (either through purchase or production) is the most serious problem for most urban poor in Nigeria, therefore, most urban dwellers farm to secure food for their households.

Table 3 also showed that $42.86 \%$ of the respondents produce to earn more income. This result agrees with London-Lane (2004), Reuther and Dewar (2005), Kekana (2006) and Idowu et al (2012) that urban agriculture is undertaken by individual households generally to augment household's real income. This underscores the need for suitable policies to improve urban crop farming to enable producers to adequately access food and income for other necessities.

\subsection{Determination of Factors Affecting Respondents' Productivity}

A Cobb Douglas production function was employed to determine the factors affecting respondents' productivity. Results show that the coefficient of determination $\left(\mathrm{R}^{2}\right)$ was 0.519 indicating that $51.9 \%$ of the variation in output was explained by variables included in the model. The F- Ratio which gives the overall significance of the regression was 55.29. This is statistically significant at 5\% level of probability implying that the combined influence of the explanatory variables $\left(\mathrm{X}_{1}, \mathrm{X}_{2}, \mathrm{X}_{3}, \mathrm{X}_{4}\right)$ is strong on the output( $\left.\mathrm{Y}\right)$. The estimated regression equation is given as:

$$
\log Y=1.77+0.340 X_{1}+0.067 X_{2}+0.234 X_{3}+0.558 X_{4}
$$

The t-test carried out on the regression coefficients show that the coefficients for farm size $\left(\mathrm{X}_{1}\right)$, amount of fertilizer applied $\left(\mathrm{X}_{3}\right)$, the quantity of seeds and other planting materials $\left(\mathrm{X}_{4}\right)$ were statistically significant at 5\% level of probability. This implies that farm size, amount of fertilizer applied, the quantity of seeds and other planting materials used were the variables that significantly predicted variations in the dependent variable $(\mathrm{Y})$. This implies that significant determinants of respondents' output are farm size, amount of fertilizer applied, and quantity of seeds and other planting materials. There is need for policy makers on urban agriculture to take into consideration these significant variables in order to ensure that the needs of producers are met for optimum productivity.

By the nature of Cobb Douglas production function, the coefficients of the various explanatory variables are elasticities and the results have the following implications:

Farmsize $\left(X_{I}\right)$ : The coefficient of farm size $(0.340)$ is positive and statistically significant at $5 \%$ level of probability indicating that farm size is an important factor explaining changes in production. If farm size is increased by 10 percent, output level would tend to rise by 3.4 percent, all things being equal. This implies that the magnitude of the coefficient shows inelastic output response to farm size. The coefficient is statistically significant at 5 percent indicating that output per plot can be increased by unit increase in farm size. This result in line with Morris (2001), Herath and Takeya (2003), and Idowu et al (2012). 
Amount of labour used in man-days $\left(\mathrm{X}_{2}\right)$ : The coefficient of amount of labour used is 0.067 . This is not statistically significant.

Amount of fertilizer applied $\left(X_{3}\right)$ : The coefficient of amount of fertilizer applied is 0.234 . It is positive and statistically significant at 5\% level of probability meaning that farm size is an important factor explaining changes in production. If the amount of fertilizer applied is increased by 10 percent, output level would tend to rise by 2.34 percent, all things being equal. This implies that the magnitude of the coefficient shows inelastic output response to amount of fertilizer applied. The coefficient is statistically significant at 5 percent indicating that output per plot can be increased by unit increase in the amount of fertilizer applied. This conforms to a priori expectation and agrees with Odii (2003) that use of agricultural technologies such as fertilizers have positive effect on output and productivity.

Quantity of seeds and other planting materials used $\left(\mathrm{X}_{4}\right)$ : The value of the coefficient is 0.558 . This is positive and implies that production elasticity of output with respect to quantity of seeds and planting materials is 0.558 . This is an inelastic situation which implies that if quantity of seeds and planting materials are increased by 10 percent, output level would tend to improve by a margin of 5.58 percent ceteris paribus. The coefficient is statistically significant at 5 percent. This implies that there is scope for increasing output per plot by increasing quantity of seeds and planting materials. This result agrees with a priori expectation, and it is in line with Olayiwola (n.d). Furthermore, the sum of the regression coefficients is 1.229 indicating increasing returns to scale. This is in line with Koutsoyannis (1977) and Sankhayan (1988), and it implies that greater volume of output could be generated if these farmers increase the use of all inputs.

\section{Conclusion And Recommendations}

This study was undertaken to assess the contribution of urban crop production to the socio-economic development of Benue State, Nigeria. The study showed that through the provision of more food, income and avenue for relaxation for urban crop farmers, urban agriculture has enhanced farmers' welfare and contributed positively to the socio-economic development of Benue State, Nigeria. However, there is need for appropriate urban agriculture policies, which if properly implemented, could remove identified constraints and enable urban agriculture (particularly crop production) to contribute maximally towards food security and poverty reduction in the study area, and help mitigate the worsening economic situation in the country.

Based on the findings of this study, the following recommendations are made towards improving urban crop production in Benue State, Nigeria:

Since land is one of the significant determinants of urban output in this study, provision of more land could serve as an incentive for more cultivation, more income and reduction of food shortages, and poverty in the study area. Therefore, the practice of urban agriculture should be legalized and incorporated into town plans in order to enhance land availability and security for urban agriculture.

The study also demonstrated that the amount of fertilizer applied has a positive significant effect on respondents' output and productivity. However, fertilizers are very expensive and unaffordable to majority of farmers in the study area. This calls for policies that would make the relevant fertilizers both available and affordable to farmers in the study area.

The study revealed that seeds and other planting materials are significant determinants of respondents' output and productivity. Therefore, provision of improved seeds and other planting materials through appropriate agricultural services such as extension services and microfinance specially targeted at urban crop producers would enable them to optimize production and welfare.

The study further showed that respondents paid more attention to the quantity more than quality aspects of food security in their crop production choices. They produced mostly basic starchy staple foods without much attention to qualitative foods such as vegetables, fruits and pulses (see Table 2). There is need for polices to educate urban crop farmers to produce and consume foods that would balance their diets for them to enjoy quality lives.

\section{References}

[1]. Adeyemo, R. and F. Kuhlmann, (2009). "Resource use efficiency in urban agriculture in South-western Nigeria'. Tropicultura, 27:49-53.

[2]. Agbamu (2006). Essentials of agricultural communication in Nigeria. Malthouse Press Limited Lagos.

[3]. Ajibefun, I.A. and Aderinola, E.A. (2004). "Determinants of technical efficiency and policy implications in Traditional Agricultural production: Empirical study of Nigerian food crop farmers”'. Final Report presented at Bi-annual Research Workshop of African Economic Research Consortium, Nairobi, Kenya.

[4]. BNARDA (2001). "The impact of Benue State Agricultural and Rural Development Authority on Agriculture and Rural Development in Benue State'”. BNARDA Makurdi, Nigeria.

[5]. Cofie, O. (2008). "Emerging issues in Urban and peri-Urban agriculture (UPA) in West Africa": Brief Note. International Water Management Institute Publication, pp:http://ruaf.iwmi.org/Data/Sites/4/PDFs/UPA\%20paper\%20for\%20REFILS_Cofie.pd

[6]. Dessus, S., Herrera, S. and R. de Hoyos (2008). ; "The impact of food inflation on urbanpoverty and its monetary cost: some backof-the-envelope calculations"'.Agricultural Economics 39 (Suppl.), pp417-429.

[7]. Egbuna, N. E. (n. D.). Urban agriculture: A strategy for poverty reduction in Nigeria. Central Bank of Nigeria. Abuja 
[8]. FAO (2001). "Urban and peri-urban agriculture: A brief guide for the successful implementation of urban and peri-urban agriculture in developing countries"'. National Special Programme for Food Security (NSPFS) Abuja, Nigeria. FAO, Rome.

[9]. FAO, (2007). "Profitability and sustainability of urban and peri-urban agriculture. Agricultural Management, Marketing and Finance". Occasional Paper 19, pp: 5-24, ftp://ftp.fao.org/docrep/fao/010/a1471e/a1471e00.pdf

[10]. Foeken, D. and Mwangi, A. (2000). "Increasing food security through urban farming in Nairobi. In: Hovorka A. (eds). Women Feeding Cities: Mainstreaming gender in urban agriculture and food security', Practical Action Publishing UK. Pp 143-150.

[11]. Garret, J.L.(2000). "Promoting Sustainable Development in Less Favoured Areas. In: Achieving Urban Food and Nutrition Security" in the Developing World 2020: Focus 3, Garret, J.L. and M.T. Ruel (Eds.). International Food Research Institute, Washington DC., USA.

[12]. Herath, PHMU and H. Takeya (2003). "Factors Determining Intercropping by Rubber small scale holders in Sri Lanka: A Logit Analysis". Journal of Agricultural Economics 29; $159-168$

[13]. Hovorka, A., Zeeuw, H. and Njenga, M. (2009). Women Feeding Cities: Mainstreaming Gender in Urban Agriculture and Food Security. Practical Action Publishing Ltd.U.K. Pp 5-20.

[14]. Idowu O., Cofie O and Adeoti A.(2012). "Gender analysis of land use for urban agriculture and sustainability of livelihoods in Freetown, Sierra Leone'. African Journal of Agricultural Research Vol. 7(5), pp. 676-683, 5 February, Available online at http://www.academicjournals.org/AJAR accessed on 20/03/2013.

[15]. Inoni, O.E. (2008). "Impact of rural roads and marketing infrastructure on output and income of farming households in Ughelli South Local Government Area, Delta State'. Proceedings of the $10^{\text {th }}$ Annual National Conference of the Nigerian Association of Agricultural Economists held at University of Abuja, $7^{\text {th }}-10^{\text {th }}$ October

[16]. Kekana D.S. (2006). "A socio-economic analysis of urban agriculture: The Soshanguve Project Case Study". Unpublished M.A. thesis. University of Pretoria.

[17]. Koutsoyannis, A. (1977). "Elements of econometrics". Macmillan Press Limited, London.

[18]. Koutsoyiannis (2001). "The Theory of Econometrics". $2^{\text {nd }}$ Edition. New York. Palmgrave.

[19]. London-Lane, C. (2004). "Diversifying rural incomes through home gardens". Rome. FAO.

[20]. Lynch, K.; Binns. T. and Olofin, E. (2002). "Urban agriculture under threat: The land security question in Kano, Nigeria". Available at http://www.city.farmer.org/landsecurity/Kano

[21]. Morris, M. L. (2001). "How does gender affect the adoption of Agricultural innovations? The case of maize technology in Ghana". Journal of Agricultural Economics (25): 2739.

[22]. Mougeot, I. (2006). "Growing better cities". In: Urban agriculture for sustainable development, IDRC part. 1

[23]. National Bureau of Statistics (2005). Poverty profile in Nigeria. National Bureau of Statistics, Abuja

[24]. Odii, M.A.C.A.(2003). "Effect of improved technologies on gender productivity in cassava production'”. Journal of Agric. and Social Research. JASR Vol.3, No.1.

[25]. Ogungbile, A.O.(2008). "Poverty reduction and access to agricultural inputs'. Nigeria Association of Agricultural Economists. Economic and Policy Series Vol.1 No.1 October p34-38.

[26]. Ogunlade, I. C.G. Omokanye and A.A. Adeniji (2007). “An assessment of farmers' interest in university of Ilorin poultry research result', Int. J. Poult. Sci., 6: 283-288.

[27]. Okolo, D. A. (2006). "Agricultural development and food security in Sub-Saharan Africa; the case of Nigeria", FAO working paper No. 5 .

[28]. Oladeebo, J.O. and A.I. Ambe-Lamidi, 2007. "Profitability, input elasticities and economic efficiency of poultry production among youth farmers in Osun state, Nigeria”. Int. J. Poult. Sci., 6: 994-998.

[29]. Olaniyi, A.O. (2012). “Attitudinal disposition of urban dwellers towards participation in urban agriculture in Oyo State, Nigeria: implication for sustainable food production". Asian Journal of Agricultural Research, 6: 1-11.

[30]. Olayemi, J. K., and Olayide, S. O (1981). "Elements of Applied Econometrics', CARD, Ibadan.

[31]. Olayide, S.O. and E.O. Heady (1982). "Introduction to Agricultural Production Economics'. Ibadan University Press

[32]. Olayiwola, O.O (n.d.). "Appraisal of urban agriculture in Abuja, Nigeria”. National Monthly Referred Journal of Research in Commerce and Management, Vol.1, Issue No.9 ISSN 2277-1166.

Available at www.abhinavjournal.com accessed on 25/08/2013

[33]. Onyenweaku,C.E., K.C. Igwe, and J.A. Mbanasor (2004). "Application of stochastic frontier in the measurement technical efficiency in yam production in Nassarawa state, Nigeria". J, Sust. Trop. Agric. Res., pp13.

[34]. Reuther S, Dewar N (2005) 'Competition for the use of public open spaces in low income areas: The economic p'otential of urbn gardening"' in Khayelitsha, Cape Town. Dev. Southern Afr., 23(1): 97-122. ,

[35]. Ruel, M.T., Carret,JI, Morn,S.S., Maxwel, D., Oshaung,A., Engle, P., Menon, P., Slack, A., Haddad, I. (1998). "Urban challenges to food and nutrition security: A Review of Food Security, Health, Care-giving'” in the Cities. PLND Discution Paper No. 51 IFPRI Washington DC.

[36]. Salau, E. S. and Attah, A. J (2012). “A socio-economic analysis of urban agriculture in Nasarawa State, Nigeria” PAT 8 (1): 1729; ISSN: 0794-5213 available at www.patnsukjournal.net/currentissue accessed on 28-03-2013.

[37]. Sankhayan,P.L(1988). "Introduction to economics of agricultural production". Prentice Hall of India.

[38]. Umoh, G. S. (2006). "Resource use efficiency in urban farming: an application of stochastic frontier production function'” International Journal of Agriculture and Biology. Available at http://www.fspublishers.org accessed on23-03 -2013.

[39]. UN (2008). "World urbanization prospects: the 2007 revision”. United Nations, Department of Economic and Social Affairs, Population Division, New York. http://esa.unorg/unup.

[40]. UNDP (1996). "Urban agriculture. food, jobs, and sustainable cities”. United Nations Development Programme. Publication Series for Habitat II, vol. 1. UNDP, NewYork

[41]. UNICEF. (1995). "Strategy for improved nutrition of children and women in developing countries". UNICEF Policy Review Paper. New York: UNICEF.

[42]. Zezza, A., Azzarri, C., Davis, B., Covarrubias, K., Tasciotti, L., and G. Anriquez (2008). "The impact of rising food prices on the poor'. FAO-ESA Working Paper 08-07

[43]. Zezza, A. and Tasciott,i L. (2010). "Urban agriculture, poverty, and food security: Empirical evidence from a sample of developing countries'. Food policy 35, Agricultural Development Economics Division, Food and Agriculture Organization (FAO), Viale delle Terme di Caracalla, 00153 Rome, pp265-273. 